\title{
Geospatial Distribution and Analysis of Trace Element Geochemistry along the lower Reaches of Kassa River System Younger Granite Province, North Central Nigeria
}

\author{
Nimlang H. N $\mathbf{N}^{1}$, Piwuna R.M ${ }^{2}$, Gwamzhi M. $\mathrm{J}^{3}$ and Alaga A.T ${ }^{4}$ \\ ${ }^{1}$ Department of Geology, National Centre for Remote Sensing, Jos. Plateau State, Nigeria \\ 2Department of Geology, Faculty of Natural Sciences, University of Jos Jos Plateau State Nigeria \\ ${ }^{3}$ Halita Engineering Services Gut Central, Rayfield Jos, Plateau State, Nigeria \\ ${ }^{4}$ Advanced Space Technology Application Laboratory (National Space Research and Development Agency) \\ Ile-Ife, Osun State, Nigeria
}

\begin{abstract}
A study was conducted to investigate the Geospatial distribution of trace elements including Iron along the lower reaches of the Kassa river system within the Younger granite province of North Central Nigeria. A total of thirty sediment sample were collected to investigate the concentration and potential environmental effects of trace elements within the area of study. The X-Ray fluorescence spectroscopy was used to determine the concentration of the trace elements including Iron while geographic information system technique of interpolation was used to interpolate not the element present but their ambient concentration as well. Results showed that the relative concentration of trace elements in the lower reaches of the Kassa river sediments is in the order $\mathrm{Fe}>\mathrm{Ze}>\mathrm{Pb}>\mathrm{Th}>\mathrm{Rb}>\mathrm{Nb}$. Pollution Load Index values of studied area ranged from 0.596-1.476ppm which testify that the river sediments are mostly unpolluted except for two of the sampling sites. However, the Igeo values indicate that anthropogenic activities in the study area contribute to the distribution and concentration of the trace elements within the area of study.
\end{abstract}

Keywords: Younger Granites, Kassa river, Trace elements, River sediments, Geospatial distribution.

\section{INTRODUCTION}

Trace elements could have many names as well as many definitions. Depending on the field of study, trace elements are also known as potentially toxic elements, trace metals, heavy metals, micronutrients, and minor elements. However, geologists define trace elements as any element/elements in rocks other than the most abundant eight elements found in the Earth's crust. Trace elements are present in soils from the underlying parent material. Trace elements are present in many minerals and ore deposits that make up different rocks and geologic units. Their concentrations in rocks are dependent on the trace element concentrations within rock forming minerals. Their concentration in soils and stream sediments are usually controlled by a variety of physical and chemical factors acting in the geologic parent material, and the trace elements tend to be immobile [1]. Anthropogenically, trace elements are common in industrial goods, byproducts of the mining industry in mine spoils, component of paints and pesticides, and constituent of land applied municipal and industrial sites. In addition, trace elements have been added to soils by the use of inorganic fertilizers by farmers, the discharge of atmospheric emissions, and spills and illegal dumping of industrial waste. According [12] trace elements are among the most common environmental pollutants and their occurrence in water and sediments indicates the presence of natural and anthropogenic sources.

Stream sediments are mixtures of sediments, soil and rocks from the drainage basin upstream of the collection site [11]. An investigation of chemical composition of stream and river sediments have been used as a prospecting tool for mineral deposits otherwise known as pathfinders [9, 17 and 16] but the same principles and techniques can be extended to more environmentallyrelated studies [7].

[18] Observed that mostly, the chemical composition of stream sediments is dependent on several factors, such as the lithology, morphology and structural setting of the catchment, and on the effect of climate, which controls weathering rates and hydrological 
features as well as the density and type of vegetation cover. In addition, anthropogenic activities can sometimes strongly influence fluvial dynamics and the environmental quality of the fluvial systems [10].

The strong association of many trace elements in stream sediments means that the distribution, transport, and availability of these constituents cannot be evaluated solely by the sampling and analysis of the dissolved phase [15]. Several means that have been employed to establish local background concentrations; these include: The average composition of some local rock type(s), Dated sediment cores which provides a historical chemical record for the specific site under investigation, and chemical averages for recent sediments from relatively unaffected areas having similar geologies [20, 22, 19, 2, 3, and 18] A simple comparison with average rock compositions are often of little use in fluvial systems due to diverse geology, petrology, landuse or hydrology. Due to the problems associated with defining useful average concentrations, it might prove more efficacious to develop a set of sediments-trace elements predictive trace elements concentrations [7].

Therefore, a thorough knowledge of the local geology and petrology is required in estimating the influence of different rock types on the composition of local stream sediments [3].

Fluvial sediments, both bed-load and suspended, can act as sink and/or carriers for a large number of pollutants that can either be transported away from source areas according to fluvial dynamics or be stored in the solid fraction of the bed sediments. Sediment transport is an important means through which contaminants/pollutants are moved mostly in clastic form, but also hydromorphically from source to areas where their ecological and human health risks are felt [14].

Keeping these views in mind, the close relationship between the geology of Ropp complex and the trace elements of stream sediments from the lower reaches of Kassa river system is studied with a view to analyzing the concentration, the geospatial distribution and the origin of these trace elements as it relates to the natural geologic processes and anthropogenic activities.

The present study aims at analyzing the concentration, geospatial distribution and interactions between trace elements and the natural environment of the geology of Ropp complex and the stream sediments along the lower reaches of Kassa river system. The study area is located between latitude $9^{\circ} 29^{\prime} 54^{\prime \prime} \mathrm{N}$ and $9^{\circ} 32^{\prime} 11^{\prime \prime} \mathrm{N}$ and longitude $8^{\circ} 53^{\prime} 04^{\prime \prime} \mathrm{E}$ and $8^{\circ} 566^{\prime} 57^{\prime \prime} \mathrm{E}$ and covers about 30 squares kilometer located in Barkin Ladi Local Government Area of Plateau state, Nigeria.

The drainage pattern as shown in Figure 1 is radial and essentially controlled by the distribution of Younger Granites outcrops by joint plain structural weaknesses. Most of the rivers within the area are observed to have their stream source from the foot of the hills at the point of contact of the mining area encountered favored by the mining activities carried out in the area. Barkin Ladi Local Government Area of Plateau State, where the study area is located is characterized by extensive anthropogenic activities from commercial to small scale farming of crops such as grains (Maize, Millets and Acha that is Hungarian rice), root crops (Yam and Cassava) and vegetables (Carrots, Cabbages and Tomatoes) amongst others to rearing of live stocks. Local mining activities along stream channels, reworking of mine dumps and tailings for cassiterites $\left(\mathrm{SnO}_{2}\right)$ and columbites $(\mathrm{Fe}, \mathrm{Mn})(\mathrm{Nb}, \mathrm{Ta})_{2} \mathrm{O}_{6}$ are practiced by the locals on a small scale.

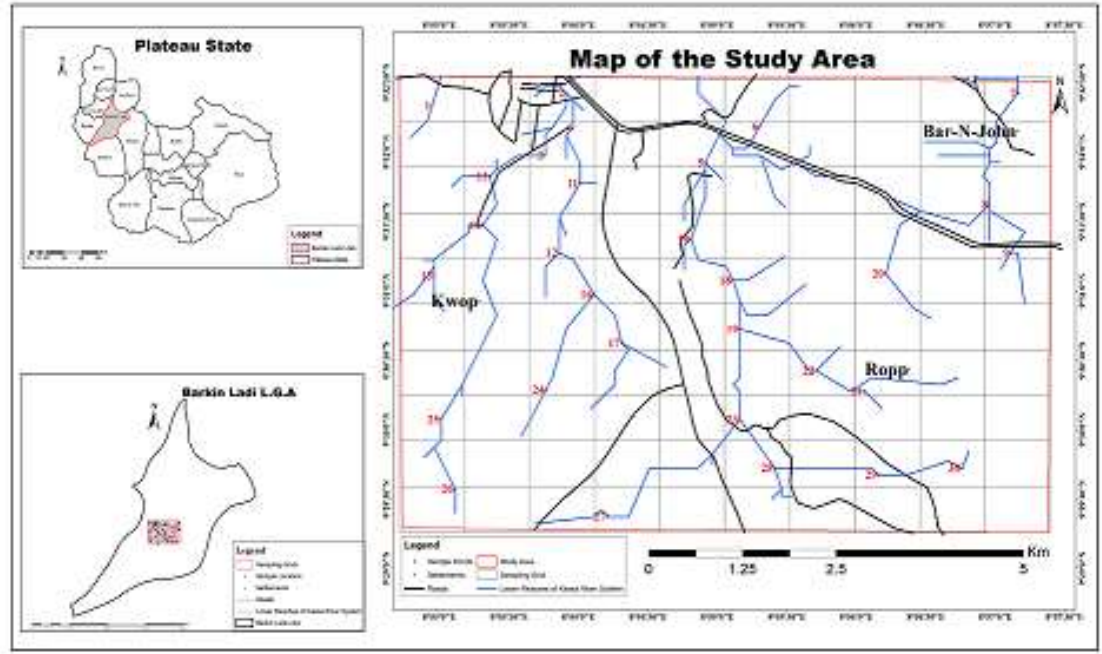

Figure 1: Location map of the Study Area. 
International Journal of Advances in Scientific Research and Engineering (ijasre), Vol 5 (6), June-2019

\section{MATERIALS AND METHODS}

From the megascopic description of hand specimens using a hand lens and further petrographic analysis of the rock slides in thinsection under a polarized microscope the rock types are observed to hornblende biotite-granites, pyroxene-granites, and porphyrygranites all belonging to the Younger Granites of the Ropp complex.

A random method of sampling of a well gridded topographical map of the study area is used in the geochemical survey with a spacing distance of about two hundred meters $(200 \mathrm{~m})$ along the lower reaches of Kassa River System. A hand auger is used to collect samples at a depth of about $20 \mathrm{~cm}$. A total of thirty (30) bulk surface oxidized bed sediment samples were collected. Representative sampling sites where established along the path of flow and the geographic locations of each sample was determine with a hand-held Global Positioning System (GPS). Proper care is taken to ensure that the sampling devices did not contaminate the sediment samples and that sample integrity is maintained.

The stream sediments samples were stored in clean sampling bags and air dried in the sunned until laboratory analysis where carried out at Centre for Energy and Training (CERT), Zaria for trace elements analysis.

Fresh rock samples of rock exposures where collected using a geological hammer which were labeled and stored in rock sample bags. Megascopic descriptions with a hand lens of these samples (observations such as colour, texture and grain sizes) and the strike and dips taken with clinometers. However, petrographic studies of slides through thin-sections under polarized microscopes are carried out at University of Jos, Jos Plateau Nigeria.

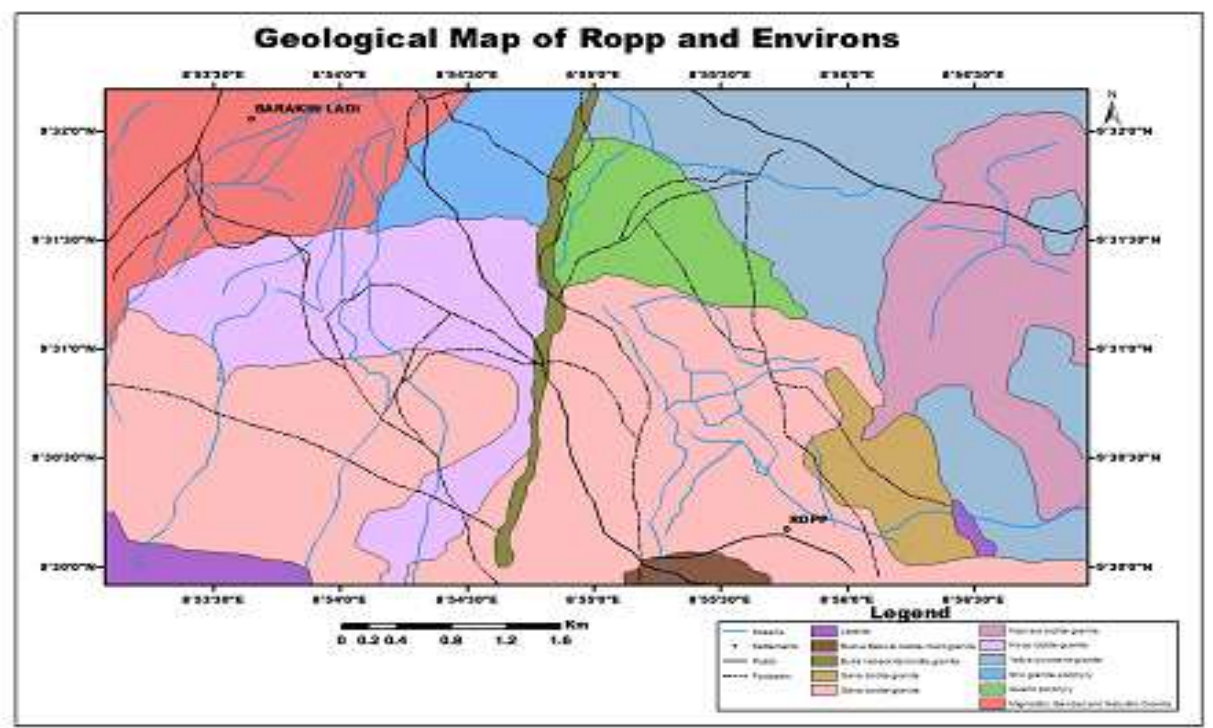

Figure 2: Geological Map of Kassa and Environs.

Other instruments used for the field study include; compasses, cameras, field note books, HB pencils, permanent markers and masking tapes.

Laboratory equipment include; Thin-sectioning machines, X-ray Fluorescence Spectroscopy (XRF) and scanners. Software used is Arc GIS $10^{\circledR}$, Integrated Land and Water Information System (ILWIS $3^{\circledR}$ ) Geomatica Focus $9{ }^{\circledR}$ Surfer 9 and Earth Resources Data Analysis System (ERDAS 9.1). Satellite Images such as Shuttle Radar Topography Mission (SRTM) images, Spot5 images, Nigeria-Sat2, mid resolution Landsat satellite images of 2015 and Nigeria-SatX images were also used for this research.

The acquired results from the different thematic data and laboratory analysis were built into a work geo-database from where different cartographic and geo-spatial analysis such as overlay, interpolation and geo-statistics were applied to determine the distribution, concentration, trend and inter-relationship between the trace elements, geology and anthropogenic activities within the study area.

X-ray Fluorescence Spectroscopy (XRF) is used to analyse for the presence of trace elements in the samples collected from the lower reaches of kassa river system.

[9] descibed X-Ray Spectroscopy as the fourth most important method of analysis for major and minor element rocks and soils. The basic principles of this method is the bombardment of samples with primary monochromatic X-ray tube. In the laboratory, the samples where first grounded with an agate motar and pestle to powder of fine grain size less than $25 \mu \mathrm{m}$, then pellets of $19 \mathrm{~mm}$ diameter were prepared from $0.3-0.5 \mathrm{~g}$ of powder mixed with three droplets of organic liquid binder (polyvinylochloride) and 
pressed afterwards using annular $25 \mathrm{ma}{ }^{109} \mathrm{Cd}$ as the excitation source that emits Mn-K X-ray (5.89Kev) in which case all elements with lower excitation energies are accessible for detection in the samples. The system also consist of a canberra $\mathrm{Si}$ (Li) detector with a resolution of $170 \mathrm{ev}$ for the $5.90 \mathrm{Kev}$ line couped to a computer ADC-cord. Quantitative analysis of the samples is carried using Emission-Transmission (E-T) method for which a number of quantification method has been developed and applied. These quantification is carried out using a modified version of E-T method and involves the use of pure target material (Mo) to measure the absorption factor is experimentatlly determined by $\mathrm{Zr}-\mathrm{K}$ is subtracted from each sample.

Sensitivity calibration of the system is performed using thick pure metal foil (Ti, Fe, $\mathrm{Co}, \mathrm{Ni}, \mathrm{Zn}, \mathrm{Nb}, \mathrm{Mo}, \mathrm{Sn}, \mathrm{Ta}, \mathrm{Pb}$ ) and stable chemical compound $\left(\mathrm{K}_{2} \mathrm{CO}_{3}, \mathrm{CaCO}_{3}, \mathrm{WO}_{2}, \mathrm{ThO}_{2}, \mathrm{U}_{3} \mathrm{O}_{8}\right)$. The spectra for the samples were collected for $3000 \mathrm{~s}$ with the ${ }^{109} \mathrm{Cd}$ and 2000 s for the ${ }^{55} \mathrm{Fe}$ source and the spectra were then evaluated using the AXIL-QXAS program.

Geostatistical and geospatial analysis of the stream sediments was carried out using Arc GIS $10^{\circledR}$. (ESTRI) through the process of interpolation. the basic process of interpolation predicts the values of cells in a raster for a limited number of samples data point. This process is used to predict unknown values for any geographic point data such a rainfall, elevation, chemical concentration and noise level. Over the years, interpolation has been proven to be a viable option because spatially distributed objects are spatially corellated; that is things that are close together tends to have a similar characteristics.

This process of interpolation is carried using Inverse Distance Weight (IDW) method which works on the principles of that estimates cell values by averaging the values of samples data points in the neighborhood of each processing cell. This method assumes the variable being decreased in influence with distance from its sample location. It is also known as a deterministic interpolation method because they are directly based on the surrounding measured values or on specified mathematical formulas that determine the smoothness of the resulting surface.

\section{RESULT AND DISCUSSION}

From the petrography and megascopic description, the area of interest is mapped and delineated to the region of interest. The different thematic data sets which include topographic, soil, geology and administrative maps is processed and digitized using a root mean square (RMS) error of $<0.00002$ while the 30m resolution Landsat image acquired in October, 2015 is classified using ENVI 4.7 with an average kappa coefficient and overall accuracy of 0.994 and $99.5 \%$ respectively. Analysis of the nature of landuse is very important in predicting the relationship between the source of trace elements in stream sediment and the surrounding natural environments [8]. The classified output is vectorized into different Land Use Land Cover thematic classes as shown in Figure 3.

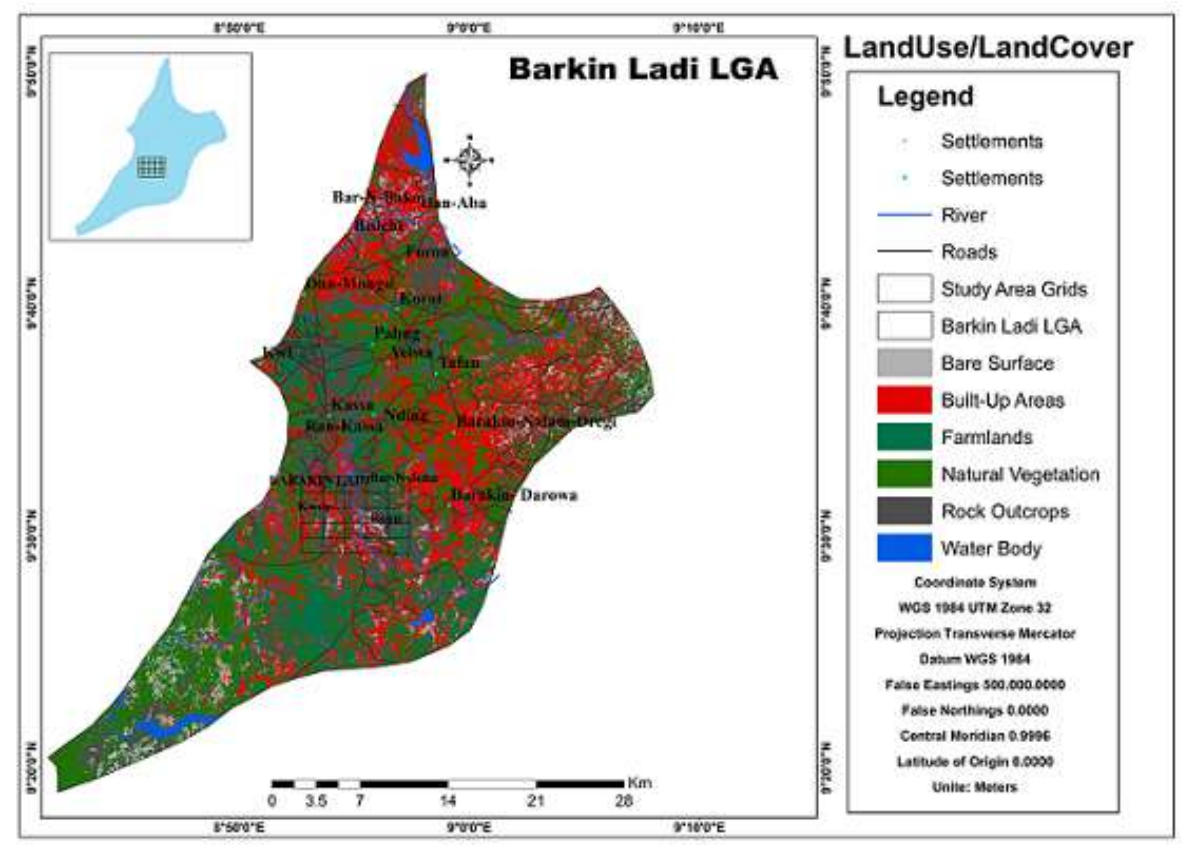

Figure 3: Landuse/Landcover map of Barkin Ladi L.G.A . 


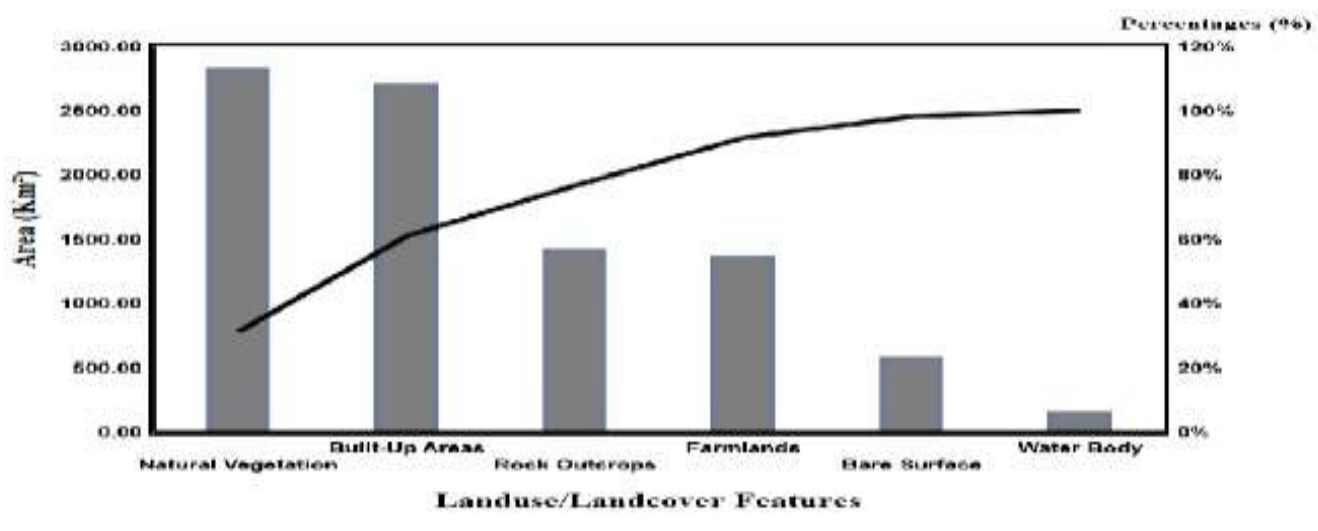

Figure 4: Graphical Representation of Landuse/Landcover map of Barkin Ladi L.GA.

The built-up area shown in Figure 3 covers $2600 \mathrm{Km}^{2}$ representing slightly above $110 \%$ of landuse/Landover function of the study area. It spans from North to South with a scattered pattern influenced by the topography, road network and mining settlements. The water bodies that are present in the study area mostly in Bar-N-Bako and Dorowa areas are majorly abandoned mine ponds. The water bodies cover less than $10 \%$, covering about $160.40 \mathrm{Km}^{2}$ of the study area is observed to be the main source of agriculture, domestic and beneficiation of locally mined/reworked mineral deposits. Agricultural farmlands occupy $1374.1 \mathrm{Km}^{2}$ representing $58 \%$ of the study area while, natural vegetation and rock outcrops occupy 2839.59 and $1424.66 \mathrm{Km}^{2}$ representing 115 and $60 \%$ respectively.

\subsection{Geospatial Distribution, Concentration and Relationship between Trace Elements and Natural Environment in the Study Area}

The trace elements geochemistry looks at the concentration, distribution and the relationship between trace elements in stream sediments, parent rock materials, mineral deposits and their relationship to other anthropogenic activities in the study area.

Summary of the result of trace elements analysis of the stream sediments of the lower reaches of Kassa river system as presented in Table 1.

Table 1: Summary of result of trace elements analysis from the stream sediments of the lower reaches of Kassa river system.

Elements

Sample No.

\begin{tabular}{ccccccc} 
& $\mathrm{Fe}$ & $\mathrm{Pb}$ & $\mathrm{Rb}$ & $\mathrm{Th}$ & $\mathrm{Zr}$ & $\mathrm{Nb}$ \\
\hline KLR01 & 5680 & 82.7 & 57.71 & 48.4 & 54.9 & 20.3 \\
KLR02 & 7300 & 119 & 31.5 & 74.9 & 83.1 & 19.7 \\
KLR03 & 92100 & 103 & 36.4 & 47.3 & 76.3 & 23.2 \\
KLR04 & 8370 & 76.6 & 47.7 & 43.1 & 69.6 & 20.2 \\
KLR05 & 7880 & 91 & 33.5 & 43.4 & 76.5 & 22.7 \\
KLR06 & 18700 & 74.8 & 33.7 & 46.9 & 47.5 & 19 \\
KLR07 & 5650 & 100 & 28.9 & 44.7 & 77.9 & 15.8 \\
KLR08 & 4500 & 91.3 & 29.4 & 49.9 & 29.09 & 76.6 \\
KLR09 & 5970 & 85.2 & 57.8 & 50.3 & 38.5 & 21 \\
KLR10 & 4890 & 76.2 & 67.8 & 40.7 & 29.07 & 19.3 \\
KLR11 & 5860 & 83.6 & 48.1 & 52.1 & 84.2 & 22.4 \\
KLR12 & 689 & 102 & 30.7 & 49.3 & 68.4 & 23.4 \\
KLR13 & 786 & 87 & 44.3 & 44.3 & 49.6 & 18.4 \\
KLR14 & 1890 & 72 & 49.2 & 52.1 & 70.2 & 24.8 \\
KLR15 & 7350 & 64 & 29.2 & 48.4 & 77.3 & 16.7 \\
KLR16 & 7302 & 78.4 & 58.14 & 78.8 & 87.2 & 23.4 \\
KLR17 & 8670 & 102 & 37.4 & 44.8 & 68.6 & 18.4 \\
KLR18 & 5790 & 89.4 & 48.6 & 50.8 & 47.5 & 26.4 \\
\hline
\end{tabular}


International Journal of Advances in Scientific Research and Engineering (ijasre), Vol 5 (6), June-2019

\begin{tabular}{ccccccc}
\hline KLR19 & 4870 & 94.6 & 29.8 & 62.9 & 30.06 & 19.8 \\
KLR20 & 6490 & 86.4 & 34.9 & 43.3 & 68.6 & 24.6 \\
KLR21 & 5690 & 106.2 & 46.8 & 52.3 & 69.5 & 17.9 \\
KLR22 & 7520 & 86.7 & 34.4 & 43.5 & 57.7 & 23.2 \\
KLR23 & 6820 & 78.5 & 53.8 & 49.2 & 78.9 & 23.5 \\
KLR24 & 8650 & 69.8 & 28.9 & 53.2 & 68.5 & 15.9 \\
KLR25 & 7480 & 58.7 & 44.5 & 46.2 & 64.2 & 19.2 \\
KLR26 & 6950 & 92.6 & 39.2 & 57.9 & 73.5 & 22.4 \\
KLR27 & 5950 & 86.5 & 33.8 & 49.3 & 58.9 & 23.5 \\
KLR28 & 4980 & 101.1 & 46.7 & 52.3 & 64.3 & 20.8 \\
KLR29 & 5940 & 64.7 & 29.9 & 48.6 & 66.2 & 17.5 \\
KLR30 & 8760 & 56.9 & 43.2 & 41.8 & 69.3 & 18.9 \\
Average & 9315.9 & 85.36 & 41.2 & 50.36 & 63.5 & 22.63 \\
Max Value & 92100 & 106.2 & 67.8 & 78.8 & 78.9 & 76.6 \\
Bac Value & 47200 & 20 & 140 & 12 & 160 & 11 \\
Cp & 1.95 & 5.31 & 0.48 & 6.57 & 0.49 & 6.96 \\
\hline
\end{tabular}

Elements analyzed include; Iron (Fe), Lead ( $\mathrm{Pb}$ ), Thorium (Th), Zirconium (Zr), Rubidium ( $\mathrm{Rb}$ ), and Niobium (Nb). The crustal averages of these elements (that is the background values) and the calculated arthmetic mean as shown in Table 1.

Iron $(\mathrm{Fe})$ is the fourth most abundant element and second most abundant metal in the Earth's crust (after aluminum). It is the most abundant transition metal in the Earth's crust, yet it is not commonly reported as a soil or sediment pollutant a high Iron loading can lead to Fe toxicity [21]. Therefore, for the purpose of this research Iron is considered along with the trace element because of its relative abundance in the stream sediment samples. Fe as observed in Figure.4 from stream sediment analysis has the highest concentration in sample location $4(18700 \mathrm{ppm})$. However, it is not anomalous when compared with the background value of $47200 \mathrm{ppm}$. Iron in the stream sediment sample of the study area is present as many rock-forming minerals, such as mica, garnet, amphibole, pyroxene and olivine. Iron becomes concentrated in mid-stage fractionates during magmatic processes and is generally enriched in mafic rocks relative to felsic, intermediate or ultramafic types. Iron in the study area is present mostly as Fe ${ }^{2+}$ in ferromagnesian silicates, such as olivine, pyroxene, amphibole and biotite, and as $\mathrm{Fe}^{3+}$ in iron oxides and hydroxides, as a result of weathering.

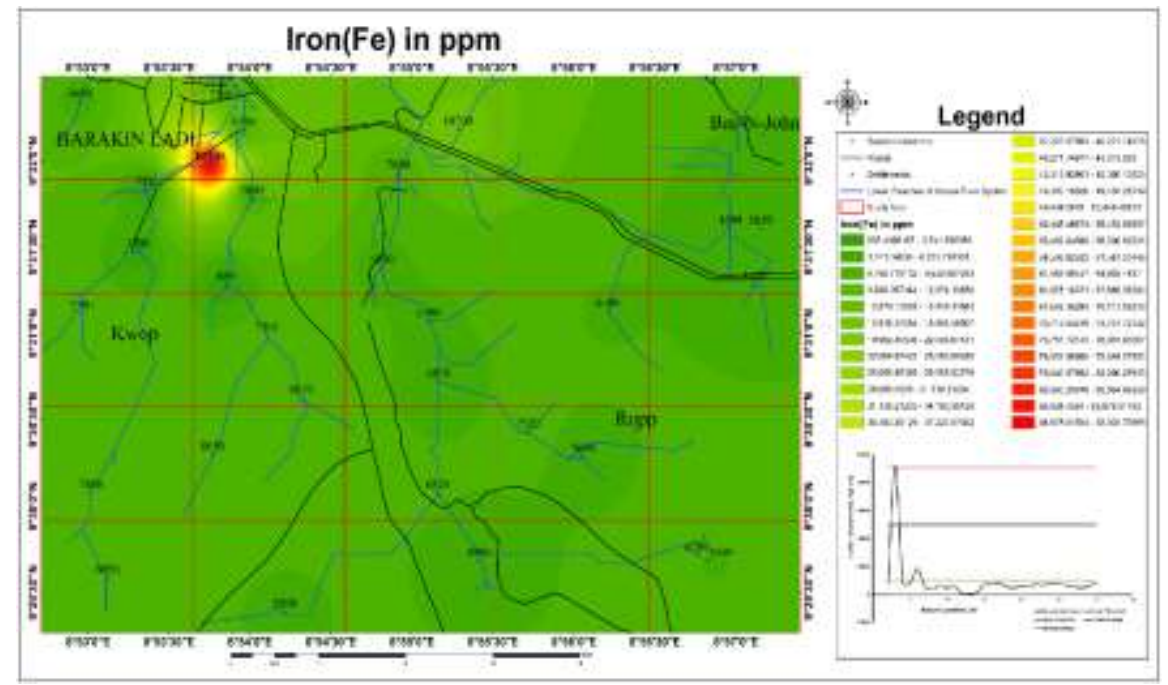

Figure 5: Geospatial Distribution of Iron (Fe) in part per million (ppm)

The highest concentration observed in the samples location four may be due to the anthropogenic activities of the locals, as it is observed that beneficiation is carried out at this location for locally mined cassiterite $(\mathrm{Sn}, \mathrm{Fe}) \mathrm{O}_{2}$.

Additionally, other anthropogenic sources of iron include the iron and steel industry, sewage, dust from iron mining and Iron sulphate used as a fertilizer and herbicide. 


\subsubsection{Rubidium in part per million (ppm)}

From the analysis (graphical, geostatistical and geospatial), of these trace elements it is observed that most of the samples show anomalous concentration with the exception of Rubidium $(\mathrm{Rb})$ which is seen to be below the background value (crustal average) of 140ppm against the calculated arithmetic mean of $47.30 \mathrm{ppm}$ as shown in Figure 6.

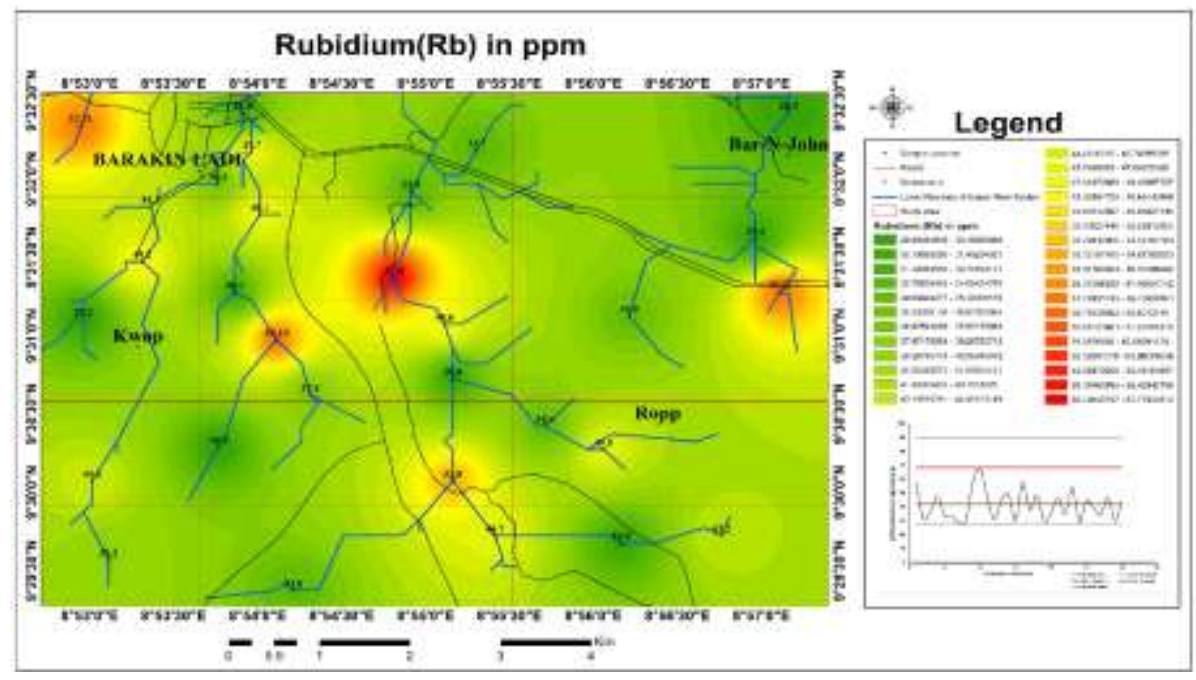

Figure 6: Geospatial Distribution of Rubidium (Rb) in part per million (ppm)

Rubidium which is known to be radioactive in nature is observed to be incorporated in must biotite and potassium feldspars with the source from igneous rocks of the study area. $\mathrm{Rb}$ is also associated with greisen-type $\mathrm{Sn}$ deposits and is found enriched in most ore zones of porphyry-copper deposits. Analysis of stream sediments along the stream channels, indicates that Rb is present mainly in K-feldspar, mica and clay minerals. During weathering, ion exchange and differential adsorption mechanisms which could concentrate $\mathrm{Rb}$ relative to $\mathrm{K}$.

The petrological analysis of the rock samples collected from the study area shows the distribution of Rb is largely controlled by the stability relationships of K-bearing phyllosilicate minerals (biotite and muscovite); breakdown of these minerals, coupled with the high solubility of $\mathrm{Rb}$ in aqueous solutions, could account for its strong depletion in medium to high pressure granulite-facies rocks. A high concentration and distribution of $\mathrm{Rb}$ is known to be used as a pathfinder in geochemical prospecting for $\mathrm{Rb}$-rich pegmatite intrusions. The strong association $\mathrm{Rb}$ with $\mathrm{K}$ and elevated $\mathrm{Rb}$ values may indicate the presence of felsic rocks, especially kaolinized intrusives as shown in the geology of the study area.

\subsubsection{Lead $(\mathbf{P b})$ in part per million (ppm)}

Lead $(\mathrm{Pb})$, surprisingly show a high concentration in all the samples of the stream sediments compared to the background (crustal average) of 20ppm as shown in Figure 7. Lead which is a chalcophile metallic element forming several important minerals including galena $\mathrm{PbS}$, anglesite $\mathrm{PbSO}_{4}$, cerussite $\mathrm{PbCO}_{3}$ and iminium $\mathrm{Pb}_{3} \mathrm{O}_{4}$ as observed in the geology of the study area. $\mathrm{Pb}$ is shown to be widely dispersed at trace levels in a range of other minerals, including $\mathrm{K}$-feldspar, plagioclase, mica, zircon and magnetite. Felsic igneous rocks are enriched in $\mathrm{Pb}$ relative to mafic rocks which are observed to form most part of the study area. The presence of primary detrital minerals, such as feldspar, mica and sulphides, clay minerals and organic materials are observed to control distribution of $\mathrm{Pb}$ in sedimentary environment such as the stream channel of the study area. 


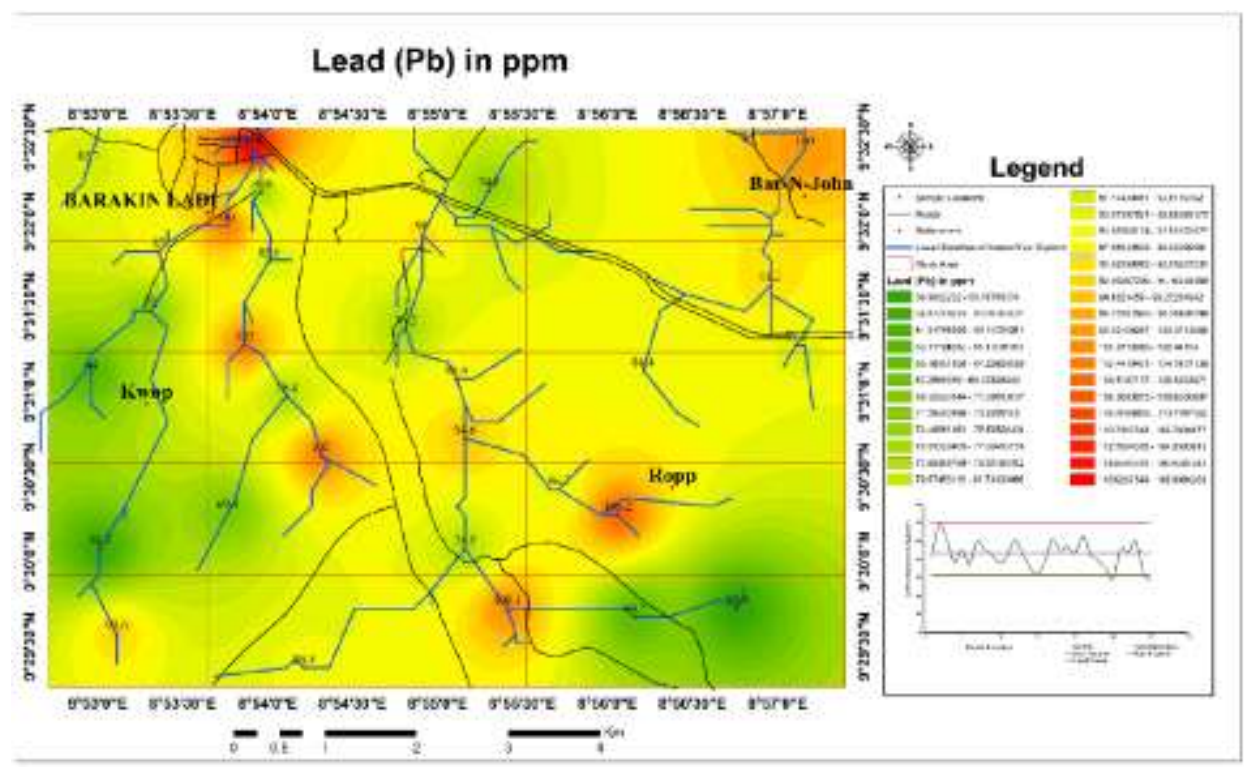

Figure 7: Geospatial Distribution of Lead $(\mathrm{Pb})$ in part per million (ppm)

Metalliferous mining (especially sulphide ores), metallic detritus, $\mathrm{Pb}$-bearing glass and pottery glazes, batteries, old lead-based paints, the corrosion of lead pipes in areas of soft water and sewage sludge could be the anthropogenic sources of $\mathrm{Pb}$ in the study area.

\subsubsection{Niobium(Nb) in part per million (ppm)}

Geospatial distribution and geostatistical analysis of the stream sediments shows that Niobium has its highest concentration at sample location eight (8) of 76.6ppm against a crustal average of $11 \mathrm{ppm}$. Nb which occurs in the mineral columbite is found in pegmatites, albite-biotite-granites and alluvial placers derived from these two rock types as observed in the geology of the study area as shown in Figure 8.

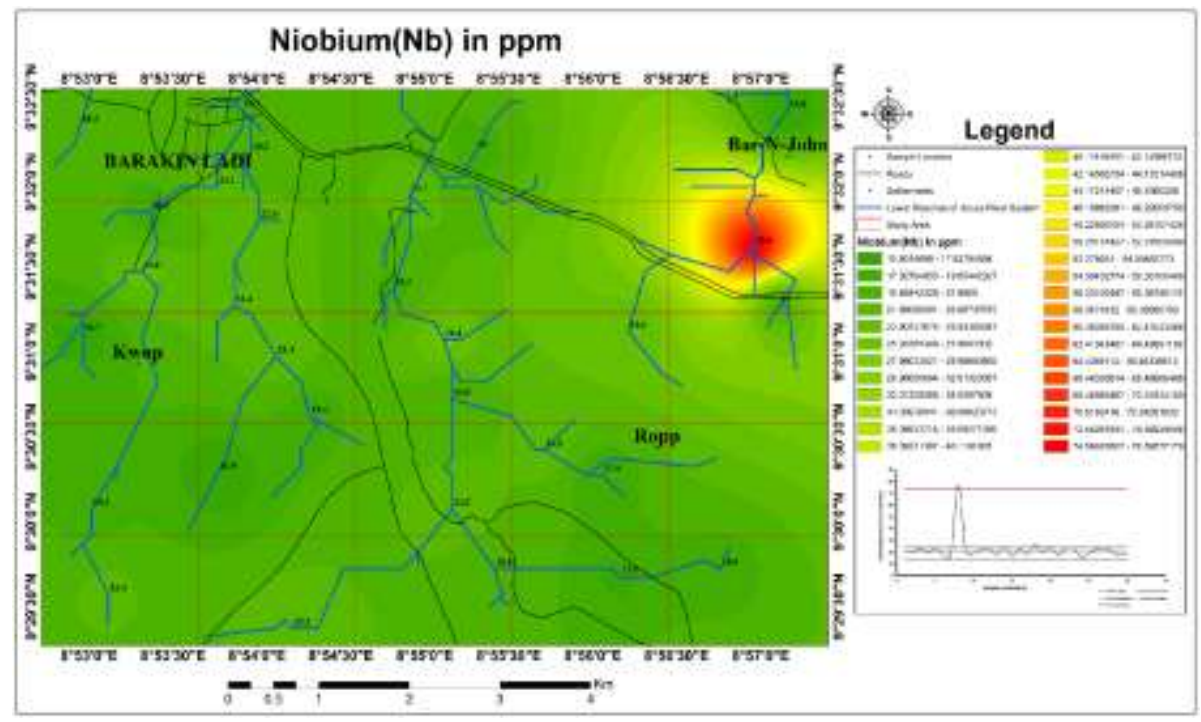

Figure 8: Geospatial Distribution of Niobium (Nb) in part per million (ppm)

The element also occurs as pyrochlore in pegmatites, albite-riebeckite-granites and alkaline igneous rocks such as carbonatites. $\mathrm{Nb}$ is observed to be widely present at trace levels in rock-forming minerals such as biotite, rutile, sphene, cassiterite and zircon; of special geochemical significance is the ionic substitution of $\mathrm{Nb}$ for $\mathrm{Zr}$ in zircon, since this mineral is widely distributed in igneous rocks which forms the predominant rock types of the study area. Ta and $\mathrm{Nb}$ mineralization are often observed to be associated with alkali granite, characterized by high fluorine levels, and by the development of pervasive, post-magmatic alteration. $\mathrm{Nb}$ also occurs in bauxite. Through petrological studies of the rock types in the study area, the alkaline rock complexes, such as syenite, nepheline syenite, alkali granite and alkaline ultramafics, are observed to have the highest $\mathrm{Nb}$ content of the magmatic rocks. 
International Journal of Advances in Scientific Research and Engineering (ijasre), Vol 5 (6), June-2019

\subsubsection{Zirconium (Zr) in part per million (ppm)}

From the geospatial distribution and geochemical analysis of the stream sediments, only sample location eight (8) has the highest concentration $165 \mathrm{ppm}$ as shown in Table 1, however compared to the crustal average of 160ppm. Within the study area it is observed that $\mathrm{Zr}$ forms several minerals including zircon $\mathrm{ZrSiO}_{4}$ and the rarer baddeleyite $\mathrm{ZrO}_{2}$. From the petrological analysis of the study area shows that $\mathrm{Zr}$ can substitute for $\mathrm{Ti}$ in ilmenite and rutile, and is also present at trace levels in clinopyroxene, amphibole, mica and garnet. Felsic igneous rocks in the study area are observed to be generally enriched in $\mathrm{Zr}$ relative to mafic lithologies.

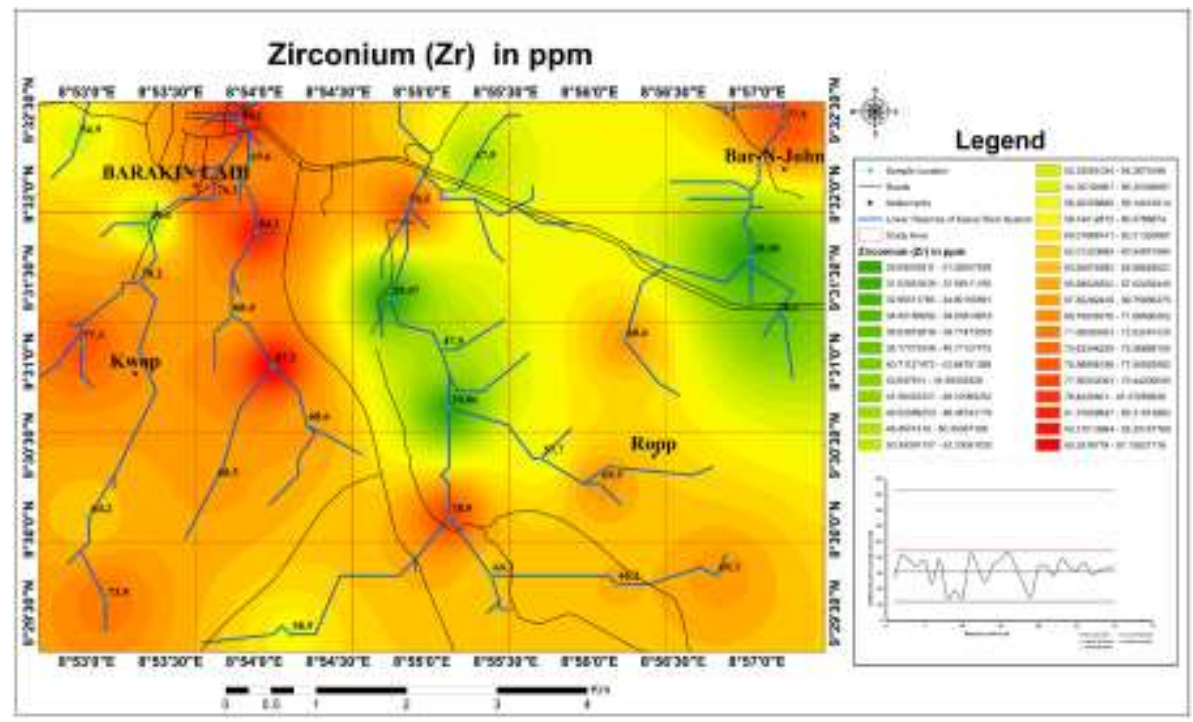

Figure 9: Geospatial Distribution of Zirconium $(\mathrm{Zr})$ in part per million (ppm)

Felsic rocks, especially intrusive which is observed to be the dominant rock composition in the eastern part of the study area are show elevated levels of $\mathrm{Zr}$. The $\mathrm{Zr}$ content in the stream sediments of the study area could be related to the presence of detrital heavy minerals, such as zircon and sphene which are generally inherited its content from the parent rocks. Zirconium displays very low mobility under most environmental conditions, mainly due to the stability of the principal host mineral zircon and the low solubility of the hydroxide $\mathrm{Zr}(\mathrm{OH})_{4}$.

There are no known anthropogenic sources of zirconium in the study area, however nuclear fallout and ceramic dusts are generally known to be highest source of $\mathrm{Zr}$.

\subsubsection{Thorium (Th) in part per million (ppm)}

Lastly, geospatial distribution and geochemical analysis show that Thorium (Th), a radioactive element has its highest concentration in sample location two $(74.90 \mathrm{ppm})$. However, this still below the crustal average of $81 \mathrm{ppm}$.

The presence of Thorium (Th) in the study area may have its source from several minerals including monazite $(\mathrm{Ce}, \mathrm{La}, \mathrm{Nd}, \mathrm{Th})\left(\mathrm{PO}_{4}, \mathrm{SiO}_{4}\right)$, the rarer thorite $\mathrm{ThSiO}_{4}$ and thorianite $\mathrm{ThO}_{2}$, but is more widely dispersed as an accessory element in zircon, sphene, epidote, uraninite, allanite and apatite in igneous rocks. From petrological analysis of the rock samples, Th is generally observed to be higher in granitic than mafic igneous rocks. Since it can enter some rock-forming minerals, such as biotite, it is not as strongly concentrated in the incompatible pegmatite phase like $\mathrm{U}$, although some Th-containing minerals, such as allanite do occur in pegmatite. 


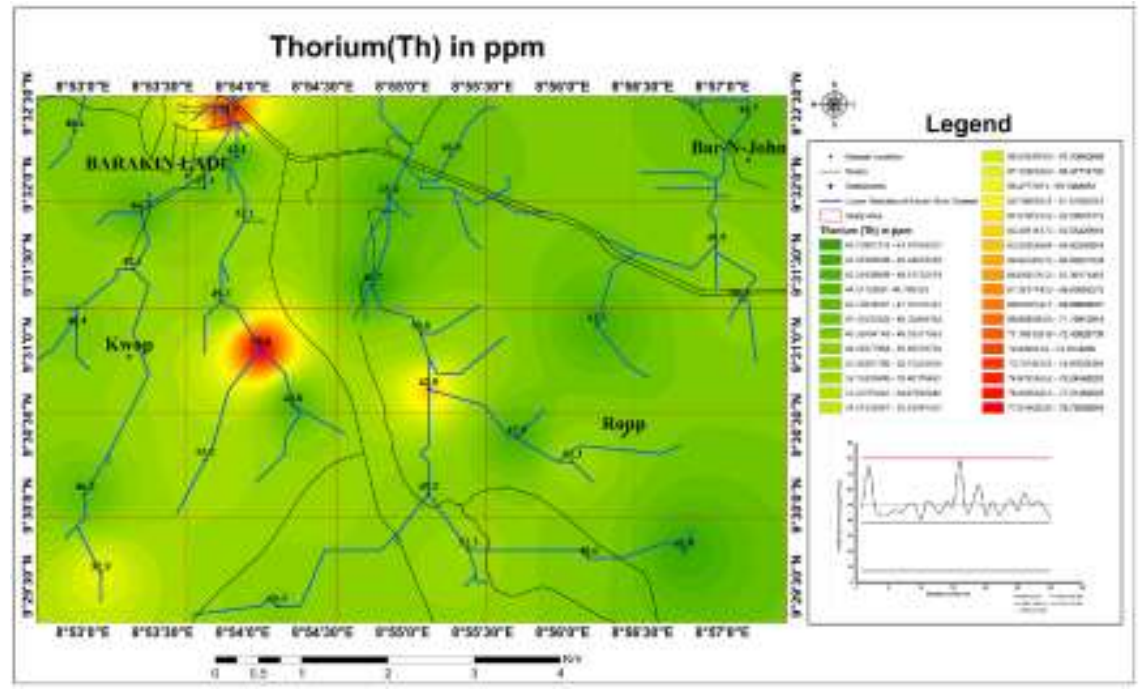

Figure 10: Geospatial Distribution of Thorium (Th) in part per million (ppm)

Th is usually more concentrated in pegmatites. Petrological analysis shows that in metamorphic rocks, the Th content is generally immobile up to the highest grades, but anataxis will result in concentration in the mobile granitic phase.

In most parts of the stream sediments, trace element analysis shows that Th is essentially resistant in character as it the major host minerals such as monazite and zircon, which are highly resistant to both chemical and physical breakdowns. Th released by weathering has a transient existence in solution as it is strongly sobbed by clay minerals as observed in the study area. Placer deposits within the study area, such as monazite sands, however, may be exceptionally rich in Th.

Anthropogenic sources of thorium within the stream sediments in the lower reaches river system could be linked to fertilizers.

\section{ENVIRONMENTAL POLLUTION}

Ascertaining the degree of contamination and distinguishing between natural and anthropogenic sources of pollution; the Contamination Factor, Pollution Load Index, Potential Contamination Index, Index of Geo accumulation and degree of contamination according to [13] is used to determine the environmental implication of trace element in stream sediments from the lower reaches of Kassa river system.

\subsection{Contamination Factor and Degree of Contamination}

Assessment of sediment contamination is done using the contamination factor and degree of contamination. The concentration of the surface (analyzed trace elements), to the background values (average shale content) helps in assessing the contamination; [6].

Contamination factor is calculated using the formula;

$\boldsymbol{C f}=\frac{\boldsymbol{C}_{\text {Trace element }}}{\boldsymbol{C}_{\text {background }}}$

Where;

$\mathrm{C}_{\text {trace element }}=$ Trace elements mean concentration in ppm.

$\mathrm{C}_{\mathrm{background}}=$ average background value of the elements in ppm.

\subsection{Pollution load index (PLI)}

The Pollution Load Index (PLI) represents the number of times by which trace elements concentrations in the sediment exceeded the background concentration, and give a summative indication of the overall level of trace elements toxicity in a particular sample and is determined as the nth root of the product of $\mathrm{nCF}$.

$P L I=\left(C_{f 1} \times C_{f 2} \times C_{f 3} \ldots \ldots \times C_{f n}\right)^{1 / n}$

Where:

$\mathrm{CFn}$ is the Contamination Factor $(\mathrm{CF})$ value of trace element $\mathrm{n}$ 
It gives simple and comparative means for assessing the trace elements pollution level in the sediment sample. The PLI values are interpreted into two levels as polluted (PLI $>1$ ) and unpolluted (PLI $<1)$. Generally, the PLI analyzed from stream sediments along the stream channels from the lower reaches of Kassa river system indicates that the concentration the trace elements are not polluted with the exception of sample location 3 and 16 with PLI values of $1.476 \mathrm{ppm}$ and $1.115 \mathrm{ppm}$ respectively as shown in Table 3 where the trace elements exceeds the PLI.

\subsection{Contamination Degree (Cdeg)}

Contamination degree is the summation of all contamination factors of all trace elements analyzed. It gives the overall contamination in the study area. Table 2 shows the classes of contamination recognized.

Cdeg $=\sum_{i=1}^{1=n} C f$

Where:

$$
\mathrm{Cf}=\text { Contamination Factor }
$$

The $\mathrm{Cd}$ is aimed at providing a measure of the degree of overall contamination in surface layers in a particular core or overall contamination in surface layers in a particular core or site.

Table 2: Contamination degree (Cdeg) Index Hakanson (1980)

\begin{tabular}{lll}
\hline Classes & Contamination degree $(\mathrm{C} \mathrm{deg})$ \\
\hline $\mathrm{Cdeg}<8$ & low degree of contamination \\
$8 \leq \mathrm{Cdeg}<16$ & Moderate degree of contamination \\
$16 \leq \mathrm{Cdeg}<32$ & Considerable high degree of \\
& contamination & \\
$32 \leq \mathrm{Cdeg}$ & Very high degree of contamination \\
\hline
\end{tabular}

From the contamination degree index shown in Table 3, Fe, $\mathrm{Rb}$ and $\mathrm{Zr}$ have low and moderate degree of contamination of $5.901 \mathrm{ppm}, 8.827 \mathrm{ppm}$ and $11.908 \mathrm{ppm}$ respectively. $\mathrm{Pb}$, Th and $\mathrm{Nb}$ on the other hand showed very high degree of contamination of $128.045 \mathrm{ppm}, 122.891 \mathrm{ppm}$ and $60.284 \mathrm{ppm}$ respectively.

\subsection{Modified degree of contamination $(\mathrm{mCd})$}

The modified degree of contamination is introduced to estimate the overall degree of contamination in the study area.

$m C f=\frac{\sum_{i=1}^{i=n} C f}{n}$

Where;

$$
\begin{aligned}
& C f=\text { Contamination Factor } \\
& \mathrm{n}=\text { Number of analyzed Trace Elements in part per million (ppm) }
\end{aligned}
$$

For the classification and description of the modified degree of contamination $(\mathrm{mCd})$ in the stream sediment, the following gradations are proposed: $\mathrm{mCd}<1.5$ is nil to a very low degree of contamination; $1.5 \leq \mathrm{mCd}<2$ is a low degree of contamination; 2 $\leq \mathrm{mCd}<4$ is a moderate degree of contamination; $4 \leq \mathrm{mCd}<8$ is a high degree of contamination; $8 \leq \mathrm{mCd}<16$ is a very high degree of contamination; $16 \leq \mathrm{mCd}<32$ is an extremely high degree of contamination; $\mathrm{mCd} \leq 32$ is an ultra-high degree of contamination. Trace elements analysis of sampled sediments from the lower reaches of Kassa river system in Table 3, the mCd shows that Fe, $\mathrm{Rb}$ and $\mathrm{Zr}$ has a very low overall degree of contamination of $0.984 \mathrm{ppm}, 1.471 \mathrm{ppm}$ and $1.985 \mathrm{ppm}$ respectively. Nb show a very high degree of contamination at $10.047 \mathrm{ppm}$ while $\mathrm{Pb}$ has an extremely high degree of contamination of $21.341 \mathrm{ppm}$. 
International Journal of Advances in Scientific Research and Engineering (ijasre), Vol 5 (6), June-2019

Table 3: Contamination factor (Cf), Pollution load index (PLI), Contamination Degree (Cdeg) and Modified Degree of Contamination $(\mathrm{mCd})$ of stream sediments along the lower reaches of Kassa River System

\begin{tabular}{cccccccc}
\hline Sample No. & & \multicolumn{7}{c}{ Elements } \\
& Fe & Pb & Rb & Th & Zr & Nb & PLI \\
\hline KLR01 & 0.12 & 4.135 & 0.412 & 4.033 & 0.343 & 1.846 & 0.897 \\
KLR02 & 0.155 & 5.95 & 0.225 & 4.242 & 0.519 & 1.791 & 0.967 \\
KLR03 & 1.951 & 5.15 & 0.26 & 3.942 & 0.477 & 2.109 & 1.476 \\
KLR04 & 0.177 & 3.83 & 0.341 & 3.592 & 0.435 & 1.836 & 0.934 \\
KLR05 & 0.167 & 4.55 & 0.239 & 3.617 & 0.478 & 2.064 & 0.93 \\
KLR06 & 0.396 & 3.74 & 0.241 & 3.908 & 0.297 & 1.727 & 0.946 \\
KLR07 & 0.12 & 5.000 & 0.206 & 3.725 & 0.487 & 1.436 & 0.828 \\
KLR08 & 0.095 & 4.565 & 0.21 & 4.158 & 0.182 & 6.964 & 0.885 \\
KLR09 & 0.127 & 4.26 & 0.413 & 4.192 & 0.241 & 1.909 & 0.869 \\
KLR10 & 0.104 & 3.81 & 0.484 & 3.392 & 0.182 & 1.755 & 0.77 \\
KLR11 & 0.124 & 4.18 & 0.344 & 3.342 & 0.526 & 2.036 & 0.928 \\
KLR12 & 0.015 & 5.1 & 0.219 & 4.108 & 0.428 & 2.127 & 0.63 \\
KLR13 & 0.017 & 4.35 & 0.316 & 3.692 & 0.31 & 1.673 & 0.596 \\
KLR14 & 0.04 & 3.6 & 0.351 & 4.342 & 0.439 & 2.255 & 0.775 \\
KLR15 & 0.156 & 3.2 & 0.209 & 4.033 & 0.483 & 1.518 & 0.822 \\
KLR16 & 0.155 & 3.92 & 0.415 & 6.567 & 0.545 & 2.127 & 1.115 \\
KLR17 & 0.184 & 5.1 & 0.267 & 3.733 & 0.429 & 0.115 & 0.599 \\
KLR18 & 0.123 & 4.47 & 0.347 & 4.233 & 0.297 & 2.4 & 0.912 \\
KLR19 & 0.103 & 4.73 & 0.213 & 5.242 & 0.188 & 1.8 & 0.754 \\
KLR20 & 0.114 & 4.32 & 0.249 & 3.608 & 0.429 & 2.36 & 0.875 \\
KLR21 & 0.121 & 5.31 & 0.334 & 4.358 & 0.434 & 1.627 & 0.933 \\
KLR22 & 0.159 & 4.335 & 0.246 & 3.625 & 0.361 & 2.109 & 0.881 \\
KLR23 & 0.145 & 3.925 & 0.384 & 4.1 & 0.493 & 2.136 & 0.99 \\
KLR24 & 0.183 & 3.49 & 0.206 & 4.433 & 0.428 & 1.446 & 0.844 \\
KLR25 & 0.159 & 2.935 & 0.318 & 3.85 & 0.401 & 1.746 & 0.858 \\
KLR26 & 0.147 & 4.63 & 0.28 & 4.825 & 0.459 & 2.036 & 0.975 \\
KLR27 & 0.126 & 4.325 & 0.241 & 4.108 & 0.368 & 2.136 & 0.867 \\
KLR28 & 0.106 & 5.055 & 0.334 & 4.358 & 0.402 & 1.891 & 0.917 \\
KLR29 & 0.126 & 3.235 & 0.214 & 4.05 & 0.414 & 1.591 & 0.784 \\
KLR30 & 0.186 & 2.845 & 0.309 & 3.483 & 0.433 & 1.718 & 0.867 \\
Average & 0.197 & 4.268 & 0.294 & 4.096 & 0.397 & 1.445 & \\
& 5.901 & 128.045 & 8.827 & 122.891 & 11.908 & 60.284 & \\
& 0.984 & 21.341 & 1.471 & 20.482 & 1.985 & 10.047 & \\
\hline & & & & & & &
\end{tabular}

\subsection{Potential contamination index $(\mathrm{Cp})$}

The potential contamination index can be calculated by the following method.

$c p=\frac{(\text { metal }) \text { sample max }}{(\text { metal }) \text { Background }}$

Where

(Metal) sample Max $=$ maximum concentration of a trace element in sediment

(Metal) Background $=$ average value of the same metal in a background level.

$\mathrm{Cp}$ values are interpreted as $\mathrm{Cp}<1$ indicates low contamination; $1<\mathrm{Cp}<3$ is moderate contamination; and $\mathrm{Cp}>3$ is severe contamination. 
Trace elements analysis of samples along the stream channels in the study area for $\mathrm{Cp}$ in Table 1 indicates that $\mathrm{Rb}$ and $\mathrm{Zr}$ has low contamination of $0.48 \mathrm{ppm}$ and $0.49 \mathrm{ppm}$. Fe shows moderate contamination of $1.95 \mathrm{ppm}$ while $\mathrm{Pb}$, Th and $\mathrm{Nb}$ shows severe level of contamination of $5.31 \mathrm{ppm}, 6.57 \mathrm{ppm}$ and $6.98 \mathrm{ppm}$ respectively.

\subsection{Index of Geo-accumulation (Igeo).}

Trace element contamination in stream sediments can be measured quantitatively by applying the concept of Geo-accumulation Index of Muller [13], expressed as;

\section{$I_{\text {geo }}=\log _{2} \mathrm{Cn} / 1.5 \times \mathrm{Bn}$}

Where;

$\mathrm{Cn}=$ measured concentration of the element ' $\mathrm{n}$ ' in the stream sediment

$\mathrm{Bn}=$ geochemical background value.

The factor of 1.5 is used because of the possible variations in the background data.

Muller's geo-accumulation index is basically a single trace element approach to quantify trace element pollution in sediments. A positive Igeo value indicates significant anthropogenic contribution to the trace element contents of the sediment while a negative value shows negligible or no contribution (Table 4).

A few of the analyzed trace elements of the study area is graphically represented in Figure 11 and Figure shown in Table 5.

Table 4: Geo-accumulation index classes

\begin{tabular}{ccc}
\hline $\begin{array}{c}\text { Sediment } \\
\text { Class }\end{array}$ & $\begin{array}{c}\text { Igeo } \\
\text { Value }\end{array}$ & Sediment Quality \\
\hline 6 & $>>5$ & Very highly polluted \\
5 & $>>4-5$ & Highly polluted \\
4 & $>>3-4$ & Moderately highly polluted \\
3 & $>>2-3$ & Moderately polluted \\
& & Moderately polluted to \\
2 & $>>1-2$ & Unpolluted \\
1 & $0-1$ & Unpolluted \\
0 & $<<0$ & Practically non (can be taken as \\
the background)
\end{tabular}

. Table 5: Geo-accumulation Index of some analyzed Trace Elements from the Lower Reaches of Kassa River System.

\begin{tabular}{ccccccc}
\hline \multirow{2}{*}{ Sample No. } & \multicolumn{5}{c}{ Elements } \\
& Fe & Pb & Rb & Th & $\mathbf{Z r}$ & Nb \\
\hline KLR01 & 0.00018 & 0.21233 & 0.02786 & 0.31094 & 0.02408 & 0.26324 \\
KLR02 & 0.00018 & 0.22983 & 0.0237 & 0.34594 & 0.02657 & 0.26061 \\
KLR03 & 0.00023 & 0.22288 & 0.02469 & 0.3091 & 0.02606 & 0.27491 \\
KLR04 & 0.00018 & 0.20864 & 0.02655 & 0.30165 & 0.0255 & 0.26281 \\
KLR05 & 0.00018 & 0.21693 & 0.02412 & 0.3022 & 0.02607 & 0.27301 \\
KLR06 & 0.0002 & 0.2075 & 0.02417 & 0.30842 & 0.02321 & 0.25745 \\
KLR07 & 0.00018 & 0.22146 & 0.02311 & 0.30457 & 0.02618 & 0.24132 \\
KLR08 & 0.00017 & 0.21708 & 0.02323 & 0.31339 & 0.02026 & 0.37935 \\
KLR09 & 0.00018 & 0.21376 & 0.02787 & 0.31403 & 0.02194 & 0.2662 \\
KLR10 & 0.00017 & 0.20839 & 0.02897 & 0.29705 & 0.02026 & 0.25882 \\
KLR11 & 0.00018 & 0.21285 & 0.02661 & 0.31685 & 0.02665 & 0.27184 \\
KLR12 & 0.00013 & 0.22241 & 0.02352 & 0.31242 & 0.0254 & 0.27566 \\
KLR13 & 0.00014 & 0.21476 & 0.02604 & 0.30385 & 0.02347 & 0.25464 \\
\hline
\end{tabular}


International Journal of Advances in Scientific Research and Engineering (ijasre), Vol 5 (6), June-2019

\begin{tabular}{lcccccc}
\hline KLR14 & 0.00015 & 0.20566 & 0.02676 & 0.31685 & 0.02556 & 0.28074 \\
KLR15 & 0.00018 & 0.2 & 0.02318 & 0.31094 & 0.02613 & 0.24617 \\
KLR16 & 0.00018 & 0.20976 & 0.02791 & 0.35001 & 0.02686 & 0.27566 \\
KLR17 & 0.00018 & 0.22241 & 0.02488 & 0.30475 & 0.02542 & 0.25464 \\
KLR18 & 0.00018 & 0.21607 & 0.02668 & 0.31482 & 0.02321 & 0.28621 \\
KLR19 & 0.00017 & 0.21879 & 0.02332 & 0.33194 & 0.02046 & 0.26106 \\
KLR20 & 0.00018 & 0.21443 & 0.02441 & 0.30202 & 0.02542 & 0.28004 \\
KLR21 & 0.00018 & 0.22435 & 0.02642 & 0.31715 & 0.0255 & 0.25224 \\
KLR22 & 0.00018 & 0.2146 & 0.02431 & 0.30239 & 0.02438 & 0.27491 \\
KLR23 & 0.00018 & 0.20982 & 0.02738 & 0.31225 & 0.02626 & 0.27604 \\
KLR24 & 0.00018 & 0.20417 & 0.02311 & 0.31852 & 0.02541 & 0.24188 \\
KLR25 & 0.00018 & 0.19584 & 0.02607 & 0.30721 & 0.02502 & 0.25837 \\
KLR26 & 0.00018 & 0.21776 & 0.0252 & 0.32531 & 0.02583 & 0.27184 \\
KLR27 & 0.00018 & 0.21449 & 0.02419 & 0.31242 & 0.0245 & 0.27604 \\
KLR28 & 0.00017 & 0.22199 & 0.02641 & 0.31715 & 0.02503 & 0.26536 \\
KLR29 & 0.00018 & 0.20052 & 0.02334 & 0.31127 & 0.0252 & 0.25026 \\
KLR30 & 0.00018 & 0.19435 & 0.02587 & 0.29919 & 0.02548 & 0.25699 \\
\hline
\end{tabular}

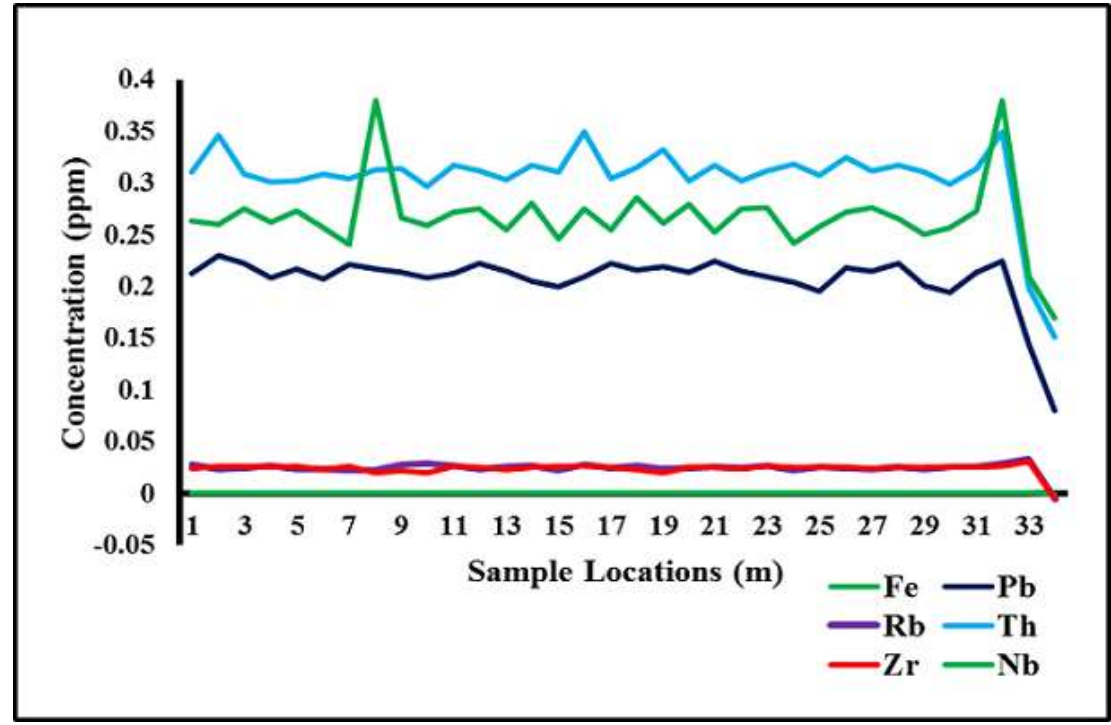

Figure 11: Graphical Distribution of Geo-accumulation Index of some analyzed Trace Elements from the Lower Reaches of Kassa River System.

Trace elements analysis along the stream channels in the study area for Igeo in Table 5 shows that all the trace elements analyzed are unpolluted. However, all the trace elements indicate that anthropogenic activities in the study area are a major factor that contributes to presence, distribution and concentration of these trace elements.

\section{CONCLUSION}

To conclude, the present study showed that the outcrops within the study area are of the Ropp Younger Granite ring complex; hornblende biotite-granites, pyroxene granites and porphyry-granites. The analysis of thirty bulk surface oxidized stream sediments showed that the relative concentration of trace elements including Iron in the lower reaches of Kassa river is in the order $\mathrm{Fe}>\mathrm{Zr}>\mathrm{Pb}>\mathrm{Th}>\mathrm{Rb}>\mathrm{Nb}$. The concentration values of the trace elements and Iron suggests contributions from identified rocks within the study area.

Findings from the methods used to determine the level of concentration showed that trace elements and Iron within the lower reaches of Kassa river are unpolluted which suggests that there is no environmental hazard due to the presence of the trace elements and Iron within the studied area though $\mathrm{Pb}, \mathrm{Th}$ and $\mathrm{Nb}$ shows severe levels of contamination. However, all trace 
elements indicate that anthropogenic activities in the study area is a major factor that contributes to the presence, distribution and concentration of the trace elements

\section{REFERENCES}

[1]. Angelides M.O, (2005) Exchange of pollutants (trace elements) at the sediment boundary. The handbook of environmental chemist, 5, 319-341.

[2]. Aston, S., Bruty, D., Chester, R., and Padgham, R. (1973) Mercury in lake sediments: a possible indicator

[3]. of technological growth. Nature (London) 241:450-451.

[4]. Forstner, U and Wittman, G. (1983). Metal pollution in the aquatic environment. Berlin: Springer-Verlag. Pp484.

[5]. Förstner, U. (1983) Assessment of metal pollution in rivers and estuaries. Applied Environmental Geochemistry (Thornton, I., ed.), 395-423, Academic Press.

[6]. Förstner, U., Ahlf, W., Calmano, W. and Kersten, M. (1991) Sediment criteria development. Sediments and Environmental Geochemistry (Heling, D., Rothe, P., Förstner, U. and Stoffers, P., eds.), 312-338, Springer-Verlag.

[7]. Hakanson, L. (1980). An ecological risk index for aquatic pollution control. A sedimentological approach. Water Resources, 28. 975-1001.

[8]. Horowitz, A., Elrick, K., and Hooper, R. (1989) The prediction of aquatic sediment-associated trace element concentrations using selected geochemical factors. Hydrol. Proc. 3:347-364. Howarth, R. J. and Thornton, I. (1983) Regional geochemical mapping and its application to environmental studies. Applied Environmental Geochemistry (Thornton, I., ed.), 4173, Academic Press.

[9]. Krishnamurthy. J, Kumar., N.V., Jayaraman, V. and Manivel, M. (1996). An Approach to demarcate groundwater potential zones through remote sensing and geographical information system. Int.J. Remote sensing, 17, pp. 1867-1884.

[10]. Levinson, A. A. (1974) Introduction to Exploration Geochemistry. Applied Publ. Co., Calgary, 612 pp.

[11]. Mantei, E. J. and Foster, M. V. (1991) Heavy metals in stream sediments: effect of human activities. Env. Geol. Water Sci. $18,95-104$.

[12]. Mikoshiba U.m, Imai N, Terashima S, Tachibana Y, Okey T (2006) Geochemical Mapping in Northern Honshu, Japan. Applied Geochemistry 21: 492-514.

[13]. Mohiuddin, K. M., Zakir, H. M., Otomo, K., Sharmin, S.; Shikazono, N., (2010). Geochemical distribution of trace metal pollutants in water and sediments of downstream of an urban river. Int. J. Environ. Sci. Tech., 7 (1), $17-28$ (12 pages).

[14]. Muller, G (1969): Index of Geoaccumulation in sediments of Rhine River, Geol. Journal (2). 108-11.

[15]. Nuhu M. W, (2014) Environmental Geochemistry of Soil and Stream Sediments from Birnin-Gwari Artisanal Gold Mining Area, North-Western Nigeria. Universal Journal of Geosciences 2(1): 18-27.

[16]. Ongley, E., Birkholz, D., Carey, J., and Samoiloff, M. (1988) Is water a relevant sampling medium for toxic chemicals? an alternative environmental sensing strategy: /. Environ. Qual. 17:391-401. Plant, J. and Hale, M. (1994) Drainage geochemistry. Handbook of Exploration Geochemistry, Vol. 6 (Gowett, G. J. S., ed.), Elsevier, 792 pp.

[17]. Rose, A. W., Hawkes, M. E. and Webb, J. S. (1979) Geochemistry in Mineral Exploration. 2nd ed., Academic Press, 657 pp.

[18]. Salomons, W. and Förstner, U. (1984) Metals in the Hydrocycle. Springer-Verlag, 349 pp.

[19]. Thomas, R. (1972). The distribution of mercury in the sediment of Lake Ontario. CanJ.Earth Sci. 9:636-651.

[20]. Turekian K. K, and Wedepohl, K. H (1961) Distribution of the Elements in some Major units of the Earh's Crust. Geological Society of America Bulletin 72: 175-192.

[21]. Von der Heyden, B.P., and Roychoudhury, A.N (2015) Application, chemical interaction and fate of Iron minerals in polluted sediment and soil. Current Pollution Reports, 1, 265.

[22]. Wedepohl, K.H. (1969) Composition and abundance of common sedimentary rocks. In: Handbook of Geochemistry, K.H. Wedepohl (éd.), Springer-Verlag, New York, 250-271. 